\title{
Wife Battery: A Divine Command from the Garden of Eden or a Gene Disorder in Men? Ethical Perspectives
}

\author{
George Anderson Jnr (PhD Can.) \\ Joseph Oppong $(\mathrm{PhD})$ \\ Department of Religion and Human Values, University of Cape Coast, Cape Coast
}

\begin{abstract}
In the past, women in the Ghanaian traditional societies were mostly not actively involved in issues relating to decision-making, leadership, and public engagement in the company of men. Their place was the kitchen. That is, their responsibilities were to prepare meals, nurture the children, and tidy up the home. Besides, they were regarded as a man's bought property. In this sense, women could be subjected to any form of inhumane treatments. One of such inhumane treatments that have caught the attention of scholars, human rights activists and some NGOs is wife battery. From an ethical perspective, we raise the question, what are the ethical bases for the reasons why men subject their wives to battery? Could it be a divine command from the Garden of Eden, a gene disorder in men or what? Using the descriptive research design of the qualitative methodology, this paper from an ethical perspective examines the act of wife battery and its effects on the family and the victim (woman). The paper argues, wife battery is neither a dictate from the Garden of Eden nor a gene disorder in men, however it is rather an erroneous socialisation of men towards how they should treat women. Further to note, wife battery in its essence is an unethical behaviour. This is because the act is unjust, maleficent, reduces the worth and dignity of women, dehumanises, and alters the physical and psychological framework of women.
\end{abstract}

Keywords: Battery, wife battery, ethics, Ghana, divine command, gene, Garden of Eden, disorder, erroneous socialisation

DOI: $10.7176 / \mathrm{JPCR} / 42-03$

Publication date:March $31^{\text {st }} 2019$

\section{Introduction}

Many people in our Ghanaian society are quick to condemn violence as something that is wrong, evil and unacceptable yet, are slow to acknowledge the fact that spousal abuse (domestic violence) is a sensitive issue that must be perceived as an illegal and immoral practice.

There is reason to posit that spousal abuse is a problem that is entrenched in many societies around the world. Ghana for instance, is no exemption. Studies in spousal abuse coupled with eyewitness account indicate that this type of violence has touched the lives of many people in the world. Although social awareness and condemnation of the issue has increased in recent years, spousal abuse seems to remain as a hidden and persistent problem. Probably, it is because of the power and control the abuser wields coupled with the fear, intimidation and humiliation suffered by the victims of the abuse. In fact, women and children are often reported to be in great danger in the place where they should be safest: within their families.

For many people, the 'home' is where they face a regime of terror and violence at the hands of somebody close to them - somebody they should be able to trust. One then wonders why women and girls are in most cases the victims. In fact, violence against women is perhaps the most widespread and socially tolerated of human rights violations, cutting across borders, race, class, ethnicity and religion. The impact of gender-based violence is said to be devastating. This is because the victims of such violence often experience life-long emotional distress, mental health problems and poor reproductive health. Besides, they stand at a higher risk of contracting HIV/AIDS and intensive long-term users of health services. It is in the light of this background that we set out to question whether the act of wife battery is a divine command from the Garden of Eden, or a gene disorder in men and examine the practice from an ethical perspective.

\section{Battery and Wife Battery: A type of Physical Abuse}

Although seemingly straightforward, the definition of physical abuse varies. This is because the term has variant connotations when used in a particular discipline. Legal definitions of physical abuse typically require physical harm to have occurred. Moreover, some definitions of physical abuse do not include perpetrator intent; others reflect motive rather than injury type (Southall et. al. 2003). More importantly, it must be observed that definitions of physical abuse are culturally determined. This is in the sense that what is considered abusive in one society may not be in another (Runyan et. al 2010; Maker et. al 2005). The National Coalition Against Domestic Violence depicts physical abuse to include the physical assault, battery, and sexual assault used as part of a systematic pattern of power and control perpetrated by one intimate partner against another (National Coalition 
against Domestic Violence). Whereas the views above on physical abuse will suffice, there is the need to add some important elements to touch on some acts that could be perpetuated by a person consciously or unconsciously against another. In this regard, we hold that physical abuse includes all those injurious actions and activities perpetuated by a person consciously or otherwise unconsciously against another person resulting in the alteration of the physical appearance and formation of another person in that person's physical environment. This definition is very important because there are instances where we can abuse an unborn child consciously or unconsciously in the child's physical environment (uterus). There is also reference to adult physical abuse, sexual abuse, battery, sexual assault and others.

Away from physical abuse, we look at the term battery. In fact, the term battery is very controversial in view of its meaning and usage. In the study of science (physics) for instance, Linden \& Reddy (2002) define battery as "a device that converts the chemical energy contained in its active materials directly into electric energy by means of an electrochemical oxidation-reduction (redox) reaction" (p. 1.3). In issues relating to sexual and domestic violence, battery simply means to beat. In Sexual and Domestic Violence for instance, Ntreh (2008: 87) defines battery as "the use of excessive force of one partner over another". For him, the victim of battery may be a man or a woman. However, more women are battered than men in relationships (Ntreh, 2008: 87; Rabenoro, 2004; Kunhiyop, 2008). Ntreh (2008) goes on to note three things that battery offense requires.

a. Intentional touching (deliberate)

In fact, in battery, the offense is not involuntary. Out of hurt and distress, the culprit executes the abuse deliberately with the aim of hurting the victim.

b. The touching must be harmful or offensive.

The touching inflicts pain, injuries, and at times poses severe alteration of the victim's body. c. No consent from the victim

The culprit does not have to consult the victim before s/he physically abuses the victim.

In this paper, battery is used in its relation to the act of wife beating. For Scott (1991), wife battery is an exposure of a married woman to serious beating or repeated injuries. Fields $(1978: 1)$ has argued that wife beating is a Civil Rights problem of enormous magnitude. For him, it is a crime that has been hidden by ignorance and social attitude. Society has viewed what happens between spouses as consensual, permissible, and private. Wife beating for Fields (1978) is a physical abuse of a woman by her present or former husband or male companion. It consists of repeated blows inflicted with the intent to do harm. Threats and verbal abuse that were preceded by beating are part of a pattern of control of a wife by her husband that is basic to wife beating. Davies (1999) corroborates Field's observation and argues, wife battery may happen in thirty percent (30\%) of families but is not recognised in the public eyes.

\section{The Forms Wife Battery Takes}

Battery/wife beating takes different forms. For instance, booting, spanking, punching, pushing, biting and slapping. Aside these forms, blade cutting, hair pulling, penis pulling, caning, stepping on belly are other notable forms wife beating takes (See: Seimeniuk, Krentz, Gish \& Gill, 2010). In a report by the Gender Studies \& Human Rights Documentation Centre, it was gathered that perpetrators of wife battery use their hands, belt, cane, pestle, bicycle tire, dog chain, stick and legs to beat their wives. The victims mostly suffer from severe bruises, bodily pains, open wounds, broken bones, swollen eyes, face and cheeks, and blood oozing from their ears (http://gendercentreghana.org/?p=63).

In fact, it is important to recognise that one does not have to be married to be the victim of physical violence by a partner. Once there is a step toward a marriage-like arrangement, as in a boyfriend-girlfriend relationship, and especially if regular sex is involved, the violence rate jumps dramatically. Additionally, wife battery is not restricted to uneducated people, however, in some cases, wife beating is practiced in families of educated people too. In a study by Hennon (1976) among students living together, his much informal evidence suggest that couples who are not married have rates of violence that are as high as or higher than those married.

Actually, the issue of wife battery is more serious than a mere dispute. Many things characterise a battered wife/woman. A battered wife is uniquely dependent upon her attacker. She is glued to him legally, financially, and emotionally. Typically, battered wives feel powerless to change their victimised condition. They are filled with self-blame, believing that their actions have caused the beatings they suffer. Battered wives are trapped by an unresponsive legal system that effectively leaves them remediless against the men who seek to control them. Their plight is worse than that of rape victims because battered wives are compelled to continue living with their abusers.

\section{Some Notable Causes of Wife Battery}

It is difficult to comprehend why a man would beat his wife, a woman he calls his beloved. The question is, is the aggressiveness of men towards women in respect of subjecting them to battery a divine command from the Garden of Eden, a gene disorder in men or what? Again, will we say men's aggression towards women emanates 
from the 'fall of man' as depicted in the Genesis account in the Garden of Eden with its cause being the woman? In fact, a cursory look at the book of Genesis $(2: 1-23 ; 3: 1-24$, NRSV), reminds us of the good relationship between Adam and God. This relationship was ruined by the introduction of Eve. In fact, if we should go by this Biblical narrative about the 'fall of man' coupled with man's present state, then, there is therefore reason to attribute man's suffering to the introduction of Eve (woman). In this regard, men who toe this progression of thought would then hold the stance that ethics is not defied for battering their wife. It is no wonder that some church fathers and reformists (John Calvin, St. Augustine, Tertullian, Martin Luther and others) supported wife battery (Ntreh, 2008).

Views and theories about the causation of wife battery vary. Alokan (2013) identifies psychological (that consider personality traits and mental characteristics of the perpetrators) and social theories (consider external factors in the perpetrator's environment, such as family structure stress and social learning) as the categories of causes of wife battery. Nonetheless, space will not allow us to discuss the two theories. However, in the paragraphs below, we present some of the predominant causes of wife battery.

'Religion' is one fundamental cause identified for wife battery. By religion, we turn to Anderson (2013a) who depicts religion as the beliefs, practices, and traditions that are espoused by various religious groups that influence the lives of their adherents (p. 163). The question of religion is very delicate as far as a discussion on wife battery is concerned. This is in view of the possibility of misunderstanding and misinterpreting scriptures on how women should be treated by their male counterparts. In Christianity and Judaism for instance, the Hebrew Bible and Christian Scriptures contain story after story of violence against women: e.g. Dinah (Genesis 34), Tamar (2 Samuel 13), the Levite's concubine (Judges 19), Jephthah's daughter (Judges 11), Vashti (Esther 1), Suzannah (Daniel 13), and probably the persistent widow in Luke's Gospel (Luke 18) (Fortune \& Enger, 2006).

In view of the stories narrated in the various books and chapters of the Bible noted above, some aggressive men rest their consolation in the biblical narratives above and seem not to see anything wrong in their bid to batter their wives. Actually, later Christian texts also condone male violence against women and the domination of women. For instance, the right of chastisement was the enforcer of women's subordination in marriage. In "Rules of Marriage" by Friar Cherubino in the $15^{\text {th }}$ century for instance, (See: Bussert, 1986), one finds a careful instruction to a husband to first reprimand his wife:

"And if this still doesn't work. . . take up a stick and beat her soundly ... for it is better to punish the body and correct the soul than to damage the soul and spare the body". (p. 13)

On the same issue of using scripture as a justification to batter women, Baloyi (2013) has argued in Wife Beating Amongst Africans as a Challenge to Pastoral Care, many traditional African husbands think that they have abusing power over their wives. Baloyi (2013) regards this view as erroneous. He observes that such an erroneous view emanates from men's misinterpretation and misunderstanding of the word submission as used by the Apostle Paul in his letter to the Ephesians (Eph. 5:22-32). That is, most men have understood 'submission' as absence of women's' right, domination over women, and rigorous subjection of women to any form of abuse. Islam is of no exemption as far as the use of scriptures to "condone" wife battery is concerned. In Islam, there are texts and interpretations of texts that have been used by abusive men to justify their behaviour. In this regard, Sharifa Alkhateeb (1999) observes:

"The most abused verse is Ayah 34 of Surah 4: "Men are the protectors and maintainers of women because Allah gave more to the one than the other, and because they support them from their means. So devout women are extremely careful and attentive in guarding what cannot be seen in that which Allah is extremely careful and attentive in guarding. Concerning women whose rebellious disloyalty you fear, admonish them, then refuse to share their beds, then beat them; but if they become obedient, do not seek means of annoyance against them. For Allah is Most High, Great” (pp. 54-55).

Although for some Islamic scholars this Qur'anic verse is misunderstood and misinterpreted, majority of the abusive Muslim men use the text to justify wife battery because Allah instructs them to do so.

Another point worth noting is tradition (belief associated with the payment of dowry). Many men think that wife beating is part of their marital rights and privileges. Among some ethnic groups in Northern Ghana, some men hold the belief that the dowry they pay is tantamount to buying their wives. For this reason, they can subject their wives to any form of violence. In fact, it is very difficult to comprehend such mentality emanating from the tradition of a group of people (See: Hinga et al. 2008:170; Waruta \& Kinothi, 2000:123). In a research by Dery and Diedong (2014) among the Upper West people of Northern Ghana, we refer to what one of their male respondents opined:

"When you dowry a woman as if you're purchasing her as your property, and she disobeys you, it is alright to discipline her because she is a bought property". "When your wife refuses you sex and/or anytime you come home, and there is no food on the table and you remember how much you paid for such treatment, you feel like squeezing or even killing her'.(p. 12) 
It appears that the silence of many abused women suggest to their abusers (husbands) that they (women) accept their destiny even when they have done them actual bodily harm. Besides, battered women seem to assume that being battered is part of the marriage package (Day, 2013).

Aside tradition, Baloyi (2013) identifies childlessness or infertility as another cause of wife battery. Procreation is very important in the African concept of marriage. A marriage in which children were not born was considered to be problematic, hence, had little chance of survival. In most instances, the bride might be returned to her parents for such a reason (Mugambi, 1989:100; Mbiti, 1991:133). Furthermore, the African community traditionally holds the view that the woman is always the suspect whenever barrenness is perceived, even without medical investigation. It is in connection with this position by the African community on childbirth and fertility that Turaki (1999:106) argues that the one who was suspected of being barren in the family was treated as badly as possible. In a research by Chigudu (2004:107) amongst the Shona-speaking people of Zimbabwe, his findings point to how some husbands battered their wives as a result of their wives' inability to conceive. He cites an example of a woman who was continuously battered by her husband for eleven years owing to her inability to conceive.

Away from childlessness, impudence and nagging are considered as a heart-breaking cause of wife battery. Naturally, all men detest women who nag, are impudent, and saucy. In some instances, whereas some men who are extremely aggressive will subject women who nag, and are impudent and saucy to severe battery, other men may brush over such behaviour and leave the scene. In the Ghanaian society like some others, some married women have no respect for their husbands. They talk with impudence, no matter the location and who is present. In such an embarrassing situation, some men victims tend to control their immediate temperaments and then subject the woman to severe battery at home.

Another risk marker for wife battery is alcohol use by men. Nonetheless, there is a considerable debate about the nature of the relationship between alcohol use and violence whether it is truly causal. Many researchers hold the view that alcohol operates as a situational factor that increases the likelihood of violence in men by reducing their inhibitions, clouding judgement and impairing their ability to interpret cues (Flanzer, 1993; Kiss et al., 2012; Pandey et al., 2009; Oladepo et al., 2011; Dixon and Browne, 2003). In fact, it becomes easier for men to claim that they knew nothing about the fight that took place when they were drunk. This makes it easier for them to continue the beatings right after they have their next drink. It is true that most men, when drunk, cannot control their temper, and they beat and mistreat their wives without any apparent provocation (Baloyi 2009:142; Bowman 2003:489; Kantor 1989:174). Baloyi (2013) quotes Phiri (2003: 23) who reports of an interview she conducted in the Apostolic Church of Christ in Pietermaritzburg. According to Phiri (2003), one of her interviewees maintained that she was subjected to battery when her husband drunk alcohol. Phiri (2003) quotes her interviewee: 'When he drinks alcohol, he shouts at me. He does not give me a chance to explain' (Phiri 2003:23 as cited in Baloyi 2013). Despite conflicting opinions about the causal role played by alcohol abuse, the evidence is that women who live with men who abuse alcohol run a far greater risk of physical partner violence, and that men who have been drinking inflict violence that is more serious at the time of an assault (Dery \& Diedong, 2014; Johnson, 1996).

From the discussions above, we gather that many views and theories exist on the causes of battery. However, the paper chose to discuss religion, tradition, childlessness, nagging and impudence, and alcohol use by men as some of the causes of wife battery. In fact, aside what the paper has pointed out, spousal disagreements, false accusations, anger escalation, protracted periods of unemployment, financial issues, desperation when partner threatens to leave, jealousy and envy constitute some of the causes of wife battery.

\section{Wife Battery: Its Effects on Children and Woman}

The effects battery on its victims and people in a battery environment is enormous. However, we categorise the effects under physical, psychological and emotional.

Women who have suffered battery are often physically affected. They may pick up a devastating body injury. In some instances, victims are maimed and as Kunhiyop asserts, they may live "in a climate of fear and intimidation" (Kunhiyop, 2006:246). This may further result in the victims living in a state of insecurity and developing sleeping disorders. The psychological effect of battery on women cannot be overlooked. Victims of battery often live with psychological baggage. They have to contend with the fact that in spite of what they do to sustain the home, their husbands show no appreciation rather, they are replenished with unfair treatment. This situation in most situations has a devastating toll on the victim's psychological framework. Emotionally, victims of battery become unstable. The treatment they receive from their husbands adversely affects their output at their work places and if they are students, it could affect their academic performance.

Children who live in such abusive an environment are affected by the treatment meted out to their mother. Since children learn by observation, they are mostly influenced by their childhood experiences that influence their aggressiveness, as they become adults (See: Kunhiyop, 2008: 245). Older children may also tend to abuse younger siblings thinking that is the way to behave towards younger and weaker members at home. 
Wife Battery: A Divine Command from the Garden of Eden or a Gene Disorder in Men?

The question of whether the act of wife battery is a command God gave to Adam in the Garden of Eden or a gene malformation and disorder in men is very controversial. This is because Biblical and Qur'anic accounts of creation never mentioned anywhere that God/Allah commanded Adam to batter Eve-the woman. In fact, for us, it is yet to be scientifically discovered and proven that there is a particular gene in men that when it becomes disordered it spontaneously causes men to resort to battery. For us, the use of Biblical and Qur'anic text by abusive men to batter their wives is unfortunate and unfounded on any Christian or Islamic ethical principles and scientific discoveries.

The truth of the matter is, it is the traditional society that has erroneously socialised men with an unqualified justification by religion. In fact, men in the traditional society have been socialised to be aggressive and to subject women to their rule and domination. Ntreh (2008:19) observes the popular traditional maxim: men will always be men and should not be held responsible for their actions. For Ntreh (2008), this wrong socialisation should not trend in the Ghanaian society or in another society in the world, whose men share the same philosophy and batter women. This is because such erroneous socialisation motivates men to disregard the beautiful creation of God - women, who happen to be the procreator of the human race especially including men who in turn grow up to batter women.

We hold the position that wife battery is neither a divine command from the Garden of Eden nor a gene disorder in men. Rather, wife battery is a product of society's erroneous socialisation of men that has informed men over the years to look down upon women, subject them to all forms of violence, and to treat them with impunity.

\section{Wife Battery: Ethical Perspectives}

The term ethics is also known as moral philosophy. Ethics, concerns itself with the study of morality. By morality Anderson (2013a) sustains, it is the hermeneutics of human act and its quality that can be judged right or wrong in the light of a standardised set of codes (p. 165). Unlike other disciplines, the subject matter of ethics is the ought of human conduct. That is, ethics examines the moral fibre of the moral agent that can be termed as good or bad, right or wrong (MacKinnon, 2011: 3; Fagothey, 1959: 20-22). Kunhiyop (2008) defines ethics as the definitions, principles and motivations for conduct and behaviour. For him, every society is influenced by its history, beliefs and values (Kunhiyop, 2008: 1-5). Another definition of ethics comes from Pojman and Fieser (2012). The two scholars see ethics as that branch of philosophy that deals with how we ought to live, with the idea of the good, and with concepts such as "right" and "wrong" (Pojman, \& Fieser, 2012: 2). Anderson (2013b) on his part sees ethics as the branch of philosophy that scientifically studies the way of life of a group of people, which includes their customs, behaviours and patterns of adaptation and change to culture" (p. 259). By ethics here, we looking at those actions of the moral agent (in this case, men) in relation to wife battery that can be said to right or wrong.

Ethics is paramount in this paper. This is there calls for the need to examine those actions of how men that appear to ruin the worth and dignity of most women in the Ghanaian society, most especially in marriage. In this sense, the introduction of the term ethics leads us to some fundamental ethical principles (respect for autonomy, non-maleficence, beneficence, and justice) that every moral agent, in this context, men (perpetrators of battery) are to reckon with as far as their female counterparts are concerned. The recognition of these principles will reinform men on the need to acknowledge women by showing them the respect due them irrespective of women's shortcomings.

For us, it is time overdue for all women to revive the call for an emancipation, reformulation and redefinition of certain religious and social doctrines, beliefs and traditions that put them at a disadvantage over men. Nonetheless, we do not call for a rebellion, rather a renaissance. A type of renaissance that will remind men to acknowledge the fact that women have been long relegated to the background and have been subjected to inhumane traditions and beliefs which have denied them of their human freedom, feelings, emotions, and pride.

The paragraphs that follow, examine ethics of wife battery by paying close attention to four fundamental ethical principles. They are:
a. non-maleficence
b. beneficence
c. respect for autonomy/human dignity
d. justice

The ethical principle, non-maleficence involves an ethical and legal duty of moral agents to avoid harming their fellow humans (Beauchamp \& Childress, 2008). It is based on the Latin maxim, primum non nocere which translates as "First, do no harm". This principle is generally used in areas of healthcare practice including treatment procedures and the rights of patients. Nonetheless, the application of this principle is not restricted to the practice of healthcare. It is applicable when dealing with every sphere of the life of the moral agent. In fact, since the principle centres on human beings, it is no mistake when applied to power relations among married 
couples in their matrimonial relationships. We articulate that ethically men have the moral obligation to provide their wives conducive environment that is safe and which does no harm. Such environment for us allows for discussion of concerns without fear of reprisal. It should be a positive environment where values, opinions, and human personality are respected without any harassment, battery, disregard and constant abuse. Insofar as women are human beings like men, there is the need for men to reckon with the fact that wife battery defies ethics and does harm to their wives. In this case, wife battery must be condemned.

The ethical principle of beneficence needs adherence by men. Beneficence connotes acts of mercy, kindness, and charity. It is suggestive of altruism, love, humanity, and promoting the good of others. In the study of ethics, the principle of beneficence refers to a normative statement of a moral obligation to act for the others' benefit, helping them to further their important and legitimate interests, often by preventing or removing possible harms (Beauchamp, 2013). In the marriage setting, we argue that this principle be observed by men/husbands that they have the moral obligation to seek the good of their wives but not to harm them irrespective of their shortcomings. This is because their wives have the ethical/moral right to be treated with care and without harm by their husbands.

Respect for autonomy/human dignity is one important ethical principle men should adhere. Autonomy is the Latin term for "self-rule". In the study of ethics, the principle holds that human beings should always treat fellow humans as an end in themselves and never merely as a means to an end. This is because moral agents have the obligation to respect the autonomy of other persons, which is to respect the decisions made by other people concerning their own lives. The reason is that human beings are not "things," but "persons" and hence not something that can be used merely as a means. While things have a price, i.e. the kind of value for which there can be equivalent, "dignity" makes a person irreplaceable (Kant, 1996, 79).

Men in their marriage ties should hold the ethical principle of justice that holds the view that each person should be given his or her due in high esteem. Human persons are to be treated fairly and with respect. If it is accepted that human beings are created equally in the image and likeness of God, then men should not see themselves as superior to women. Women are to be seen as co-equals with men hence, they deserve to be treated with respect and dignity and not as punching bags that are destined to be receiving the punches of men.

\section{Conclusion}

The paper concludes with the position that wife battery is neither a divine command from the Garden of Eden nor a gene disorder in men. It is an erroneous socialisation of men towards how they should treat women. This socialisation has existed in ancient times and has been passed on to generations that have become part of the nature of most men. Further to note, wife battery is an unethical behaviour because the act is unjust, maleficent and reduces the worth and dignity of women, dehumanises, and alters the physical and psychological framework of women.

\section{Recommendations}

First, we recommend that there should be sanctions in societies or communities that have no measures for controlling or punishing those who batter their wives. Those that have the sanctions must see to it that they are enforced. Second, societies are to be educated on the dangers and effects of wife battery on the victim and the entire family set-up. Further to note, the education should emphasise that men and women have the same dignity and worth. Finally, wife battery must be seen as a criminal issue that needs to be reported to the appropriated law enforcing quarters (traditional or civil) for legal action to be take, but not be condoned.

\section{References}

Anderson, G. Jnr. (2013a). Religion and morality in Ghana: A reflection. Global Journal of Arts Humanities and Social Sciences, 1(3), 162-170.

Anderson, Jnr. G. (2013b). The future of Ghanaian-traditional-Akan ethics: Bleak or bright? American Journal of Social Issues and Humanities, 3(5), p. 257-258.

Alkhateeb, S. (1999). Ending domestic violence in Muslim families. Journal of Religion and Abuse, 1 (4), 49-59. Anon. (18 $8^{\text {th }}$ February, 2007). 'Where am I wrong when I beat my wife'. City Press, p. 10.

Azores, P, \& Johnson, H. (1996). Dangerous domains: Violence against women in Canada. Ontario: International Thomson Publishing.

Baloyi, M. E. (2013). 'Wife beating amongst Africans as a challenge to pastoral care', In die Skriflig/In Luce Verbi 47(1), Art. \#713, 10 pages. http://dx.doi.org/10.4102/ ids.v47i1.713

Baloyi, M. E. (2009), Patriarchal structures: A hindrance to women's rights. VDM, Saarbrucken. PMid:19597877, PMCid:PMC3290404

Beauchamp, T. (Winter 2013 edition). "The principle of beneficence in applied ethics", The Stanford Encyclopedia of Philosophy, Edward, N. Z. (Ed.). $<$ http://plato.stanford.edu/archives/win2013/entries/principle-beneficence/>. Accessed on $12^{\text {th }}$ Jnue, 
2016.

Bowman, C. G. (2003). Domestic violence: Does the African context demand a different approach?, Chicago: Cornell Law Library.

Bussert, J. (1986). Battered women: From a theology of suffering to an ethic of empowerment. Minneapolis, MN: Division in North America, Lutheran Church in America.

Chigudu, H. (Ed.). (2004).Composing a new song: Stories of empowerment from Africa. Harare: Weaver Press.

Davies, A. (1999). Violence against women and its effects. Journal of Personal Guidance. 2(2), $78-85$.

Day, S. (2013). South African women mobilize against domestic abuse.Retrieved from http://journalism.berkeley.edu/projects/southafrica/news/ abuseprinterfriendly.html

Dery, I., \& Diedong, A. L. (2014). Domestic violence against women in Ghana: An exploratory study in Upper West Region, Ghana. International Journal of Humanities and Social Science, 4(12), 1-17.

Essen, A. A. (1999). A marital guide. Journal of Marriage Violence, 8(10), 112-122.

Fagothey, A. (1959). Right and reason: Ethics in theory and practice. Rockford, Illinois: Tan books and Publishers.

Fields, M. D. (1978). Wife beating: Government Intervention Policies and Practices.

Flanzer, J. P. (1993). Alcohol and other drugs are key causal agents of violence. In: Gelles R. J., Loseke, D. R.(Eds.).Current controversies on family violence, (pp. 171-181). Thousand Oaks: CA, Sage.

Fortune, M. \& Enger, C. (March, 2006). Violence against women and the role of religion. Harrisburg, PA: VAWnet, a project of the National Resource Center on Domestic Violence/Pennsylvania Coalition Against Domestic Violence. Retrieved from: http://www.vawnet.org

Funmilola Bosede, A. (April, 2013).Domestic violence against women: A family menace. 1st Annual International Interdisciplinary Conference, AIIC 2013, 24-26.

Kant, I. Groundwork of the Metaphysics of Morals, In: Practical Philosophy, Ed. M. Gregor, (1996). 37-108. The Cambridge Edition of the Works of Immanuel Kant. Cambridge: Cambridge University Press.

Kiss, L., Schraiber, L. B., Heise, L., Zimmerman, C., Gouveia, N.,\& Watts, C. (2012). Gender-based violence and socio-economic inequalities: Does living in more deprived neighbourhoods increase women's risk of intimate partner violence? Social Science \& Medicine, 74: 1172-1179.

Kunhiyop, S. W. (2008) African Christian Ethics. Michigan, Grand Rapids: Zondervan.

Linden, D., \& Reddy, T. B. (Eds.) (2002). Handbook of batteries, (3 ${ }^{\text {rd }}$ ed.). New York: McGraw-Hill.

MacKinnon, B. (2011). Ethics: Theory and contemporary issues, (concise ed.). USA: Wadsworth.

Maker, A. H, Shah, P. V, \& Agha, Z. (2005). Child physical abuse: Prevalence, characteristics, predictors, and beliefs about parent-child violence in South Asian, Middle Eastern, East Asian, and Latina women in the United States. J Interpers Violence, 20:1406-28.

Mbiti, J. S. (1991). Introduction to African religion, (2 ${ }^{\text {nd }}$ ed.). London: Heinemann.

Mugambi, J. N. K. (1989). .African heritage and contemporary Christianity. Nairobi: Longman.

National Coalition against Domestic Violence: What is intimate partner physical abuse? Available at http://ncadv.org/files/Domestic\%20Violence $\% 20$ and $\% 20$ Physical\%20Abuse $\%$ 20NCADV.pdf Accessed April 24 2015.

Ntreh, B. A. (2008). Sexual and Domestic Violence. Cape Coast: Hampton Press.

Oladepo, O., Yusuf, O. B., \& Arulogun, O. S. (2011). Factors influencing gender based violence among men and women in selected states in Nigeria. African Journal of Reproductive Health, 15(4): 78-86.

Pandey, G. K., Dutt, D., \& Banerjee, B. (2009). Partner and relationship factors in domestic violence: Perspectives of women from a slum in Calcutta, India. Journal of Interpersonal Violence, 24: 1175-1191.

Phiri, I. A. (2003). Why does God allow our husbands to hurt us: Overcoming violence against women. Journal of Theology for Southern Africa November, 19-30.

Pojman, L. P. \& Fieser, J. (2012). Ethics: Discovering right and wrong, (7th ed.). USA: Wadsworth.

Rabenoro, M. (2004). Other forms of violence against women: Cases observed in Madagascar. Sexuality in Africa Magazine, 1(3).

Runyan, D. K, Shankar, V., Hassan, F., Hunter WM, Jain D, Paula CS, Bangdiwala SI, Ramiro LS, Muñoz SR, Vizcarra B, Bordin I A. (2010). International variations in harsh child discipline. Paediatrics, 126(3): e70111.

Siemienuk, R. A., Krentz, H. B., Gish, J. A. \& Gill, M. J. (2010). Domestic violence screening: Prevalence and outcomes in a Canadian HIV population. AIDS Patient Care and STDs.

Scott, P. (1991). Battered wives. British Journal of Psychiatry, 120, 433-441.

Southall, D. P., Samuels, M. P., \& Golden, M. H. (2003). Classification of child abuse by motive and degree rather than type of injury. Arch Dis Child. 88(2), 101-104.

Turaki, Y. (1999). Christianity and African gods: A method in theology, Scholarly contributions of PU for CHE, Institute for Reformational Studies, Potchefstroom. (Series F2, no. 75)

Waruta, D.W. \& Kinoti, H. K. (2000). Pastoral care in African Christianity. Nairobi: Acton Press. 